\title{
USE OF COMPUTERS AND COMPUTER GAMES IN PRESCHOOL EDUCATION
}

\author{
Michaela HAMPLOVÁ - Jiř́ DOSTÁL
}

\begin{abstract}
The article illustrates the results of a research which aimed at determining the extent of usage of computers and computer games in upbringing and education in nursery schools. The research was also concerned with attitudes of educators towards the use of computers in nursery schools.

A performed investigation proved, among others, that the use of computers and computer games in pre-school education is disputable; on one hand, there is a group of supporters who use computers every day, on the other hand, there are teachers who completely reject the use of computers.
\end{abstract}

Key words: computer, computer game, pre-school education, teacher.

\section{VYUŽITÍ POČÍTAČŮ A POČÍTAČOVÝCH HER V PŘEDŠKOLNÍM VZDĚLÁVÁNÍ}

Resumé: Článek seznamuje s výsledky výzkumné sondy, která se orientovala na zjištění míry využívání počítačů a počítačových her při výchově a vzdělávání v mateřských školách. Dále byly zkoumány postoje pedagogických pracovníků k využívání počítačů v mateřských školách.

Realizovaným šetřením se podařilo mj. prokázat, že využívání počítačủ a počítačových her v předškolním vzdělávání má rozporuplný charakter, na jedné straně existuje skupina příznivců, kteří počítače každodenně využívají, na druhé straně jsou pedagogové, kteří využívání počítačů zcela zavrhují.

Klíčová slova: počítač, počítačová hra, předškolní vzdělávání, učitel.

\section{1 Úvod}

Využívání počítačủ ve vzdělávání na základních, středních a vysokých školách není již ničím výjimečným. Zaměříme-li se však na mateřské školy, lze oprávněně vznést pochybnosti. $\mathrm{Na}$ základě náhodných místních šetření se prokázalo, že existují značné rozdíly, jelikož některé mateřské školy byly počítači moderně vybaveny, ostatní však nikoliv. To bylo impulzem k provedení výzkumného šetření, které by přineslo základní poznatky o využivání počítačủ $\mathrm{v}$ mateřských školách $\mathrm{v}$ rámci Olomouckého kraje a poukázalo na základní problémy a úskalí s tím spojené.

Důvodem šetření byla i skutečnost, že pozornost se v ČR stále častěji zaměřuje i tímto směrem a dochází $\mathrm{k}$ postupné modernizaci vybavení škol. Např. v roce 2011 se do vybraných ostravských mateřských škol prostřednictvím iniciativy zřizovatelů, společnosti IBM a Ministerstva školství, mládeže a tělovýchovy České republiky dostalo 68 počítačových stanic KidSmart Young Explorer v rámci celosvětové iniciativy IBM KidSmart Early Learning Program (1). Dětem předškolního věku (od 3 let) je tak umožněno naučit se zdravému př́stupu $\mathrm{k}$ informačním technologiím a hravou formou rozvíjet počítačovou gramotnost. Speciální softwarové programy, kterými jsou počítače vybaveny, napomáhají rozvíjet znalost jazyka, matematiky, vědy i humanitních oborů.

Stanice KidSmart Young Explorer jsou instalovány do mateřských škol po celé České republice. Softwarové vybavení každé počítačové stanice se skládá z šesti oddílů, z nichž každý přispívá k rozvoji odlišných znalostí, dovedností a postojů. Jako celek tak pomáhá dětem rozvíjet nejen logické myšlení, ale i časovou a prostorovou představivost, umožňuje jim procvičit si základní matematické znalosti a přispívá $\mathrm{k}$ rozvoji jazykového vyjadřování.

Obsažené programy u dětí vhodným způsobem podporují představivost a tvořivost a umožňují jim v rámci řešení daných úloh samostatně objevovat nové poznatky, k čemuž přispívá i skutečnost, že úkoly se systematicky neopakují a děti tak musí pokaždé znovu hledat kreativní řešení.

Moderní vzdělávací technologie umožňují efektivní rozvoj osobnosti jedince nejen po stránce rozumové. Tento rozvoj by měl probíhat prostřednictvím aktivního učení, kdy dítě vyvíjí učební činnost vycházející ideálně z vlastního zájmu, bez zřetelného „tlaku“, relativně bez cizí pomoci. Činnost dítěte však musí být cíleně zaměřená, řízená, kontrolovaná a hodnocená. $\mathrm{K}$ tomu, aby se děti mohly aktivně učit, je nutné vytvářet vhodné situace $s$ využitím aktivizačních prostředků. 


\section{Charakteristika vzorku respondentů}

Respondenty $\mathrm{v}$ rámci realizované výzkumné sondy byli pedagogičtí pracovníci mateřských škol na území Olomouckého kraje. Z hlediska věkové struktury byli respondenti složeni v celku vyváženě z mladších i starších pedagogů, což přehledně dokládá níže uvedená tabulka. Všichni respondenti byli představováni ženami.

\begin{tabular}{|l|c|c|}
\hline $\begin{array}{c}\text { Věková kategorie } \\
\text { respondentů }\end{array}$ & Četnost & $\begin{array}{c}\text { Relativní } \\
\text { četnost }\end{array}$ \\
\hline do 40 let & 31 & 0,437 \\
\hline nad 41 let & 40 & 0,563 \\
\hline \multicolumn{2}{|c|}{$\Sigma 71$} & 1,000
\end{tabular}

Tab. č. 1: Struktura respondentů dle věku

Nadpoloviční většinu dotázaných tvořily středoškolsky vzdělané učitelky (39 respondentů), další početnou skupinou jsou učitelky s vysokoškolským vzděláním, které byly v průzkumu zastoupeny 21 respondenty. Nejméně bylo respondentů, kteří své nejvyšší dosažené vzdělání získali na vyšší odborné škole, a to 3 učitelky. $\mathrm{Z}$ tohoto důvodu byly kategorie VOŠ a VŠ vzdělání pro účely dalšího vyhodnocování sloučeny do jedné skupiny.

\begin{tabular}{|c|c|c|}
\hline $\begin{array}{c}\text { Stupeň vzdělání } \\
\text { respondentů }\end{array}$ & Četnost & $\begin{array}{c}\text { Relativní } \\
\text { četnost }\end{array}$ \\
\hline středoškolské & 39 & 0,549 \\
\hline vyšší odborné & 3 & 0,042 \\
\hline vysokoškolské & 29 & 0,408 \\
\hline
\end{tabular}

Tab. č. 2: Struktura resp. dle úrovně vzdělání

Respondenti byli složeni z pedagogů působících na vesnických školách i městských školách. Téměř tříčtvrtinové zastoupení měli pedagogové pracující na vesnických mateřských školách, konkrétně $72 \%$. Ostatních 20 pedagogických pracovníků mateřských škol působilo ve městech.

\begin{tabular}{|l|c|c|}
\hline $\begin{array}{c}\text { MŠ, ve které } \\
\text { respondent pracuje }\end{array}$ & Četnost & $\begin{array}{c}\text { Relativní } \\
\text { četnost }\end{array}$ \\
\hline na vesnici & 51 & 0,718 \\
\hline ve městě & 20 & 0,282 \\
\hline \multicolumn{2}{|c|}{$\Sigma 71$} & 1,000
\end{tabular}

Tab. č. 3: Struktura resp. dle místní př́slušnosti 3 Výsledky výzkumného šetření
Nejdříve jsme se zaměřili na zjištění skutečnosti, $\mathrm{v}$ jaké míře mají děti př́stup $\mathrm{k}$ počítači. Podařilo se zjistit, že $\mathrm{v} 72 \%$ mají děti prístup k počítači. Ve zbylých $28 \%$ nemají děti prístup $\mathrm{k}$ počítači. $\mathrm{V}$ komparaci s průzkumem realizovaným v roce 2010 došlo k rozšíření prístupu k počítačům dětmi (srovnej Hamplová, 2010).

Dotazníková položka: Mají děti ve Vaši MŠ $k$ dispozici počitač?

\begin{tabular}{|l|c|c|}
\hline Př́stup dětí k počítači & Četnost & $\begin{array}{c}\text { Relativní } \\
\text { četnost }\end{array}$ \\
\hline ano & 51 & 0,718 \\
\hline ne & 20 & 0,282 \\
\hline \multicolumn{2}{|c|}{$\Sigma 71$} & 1,000 \\
\hline
\end{tabular}

Tab. č. 4: Př́istup dětí k počítači

Dále jsme se zaměřili na zjištění toho, jak je počítač dětmi využíván. $V$ rámci dotazníku jsme na výběr nabídli respondentům následující možnosti: didaktické výukové programy, počítačové hry, internet, počítač děti nemají $\mathrm{k}$ dispozici. 51 dotázaných učitelek shodně uvedlo didaktické výukové programy a počítačové hry jako smysluplné využití počítače pro děti $\mathrm{v}$ mateřské škole. Jen 14 učitelek dětem umožňuje objevování či hraní pomocí internetu. Možnost jiné, kterou uvedli 3 respondenti, dále neupřesnili.

Dotazníková položka: Za jakým účelem je dětmi počitač využíván?

\begin{tabular}{|l|r|r|}
\hline Účel využití počítače & Četnost & $\begin{array}{l}\text { Relativní } \\
\text { četnost }\end{array}$ \\
\hline $\begin{array}{l}\text { didaktické výukové } \\
\text { programy }\end{array}$ & 51 & 0,367 \\
\hline počítačové hry & 51 & 0,367 \\
\hline internet & 14 & 0,101 \\
\hline $\begin{array}{l}\text { počítač děti nemají k } \\
\text { dispozici }\end{array}$ & 20 & 0,144 \\
\hline jiné & 3 & 0,022 \\
\hline \multicolumn{2}{|c|}{$\Sigma 139$} & 1,000
\end{tabular}

Tab. č. 5: Oblasti využití počítače dětmi

Zajímalo nás, v jaké míře děti hrají počítačové hry. Bylo zjištěno, že nejčastěji mohou děti předškolního věku hrát počítačové hry u dotázaných učitelek několikrát za týden nebo jednou týdně, a to celkem ve $40 \%$ prŕípadů. Méně 
obvyklé je pak zařazení počítačových her každý den, toto umožňuje 7 respondentů. $1 \mathrm{x}$ za 14 dnî nebo méně častěji zařazuje počítačové hry do vzdělávání 15 učitelek mateřských škol.

Dotazníková položka: Jak často mohou hrát děti ve Vaši tř́dě počitačové hry?

\begin{tabular}{|l|r|r|}
\hline $\begin{array}{l}\text { Četnost zařazení } \\
\text { počítačových her }\end{array}$ & Četnost & $\begin{array}{l}\text { Relativní } \\
\text { četnost }\end{array}$ \\
\hline každý den & 7 & 0,099 \\
\hline několikrát týdně & 17 & 0,239 \\
\hline 1x týdně & 12 & 0,169 \\
\hline 1x za 14 dní & 4 & 0,056 \\
\hline méně často & 11 & 0,155 \\
\hline $\begin{array}{l}\text { počítač děti nemají k } \\
\text { dispozici }\end{array}$ & 20 & 0,282 \\
\hline \multicolumn{2}{|c|}{$\Sigma 71$} & 1,000 \\
\hline
\end{tabular}

Tab. č. 6: Četnost hraní počítačových her

Vyhodnocení výsledků jsme provedli zvlášt' pro mladší a zvlášt' pro starší pedagogické pracovníky. Výsledky jsou zřetelné $\mathrm{z}$ níže uvedených tabulek.

Bylo zjištěno, že mladší učitelky do 40 let věku zařazují počítačové hry dětem méně častěji, nežli jejich starší kolegyně nad 41 let. Celkem ve 24 prrípadech u starší skupiny mohou děti hrát počítačové hry minimálně jednou týdně. Z uvedeného vyplývá, že spíše mladší učitelky jsou v př́padě počítačových her pro děti rezervovanější.

\begin{tabular}{|l|r|}
\hline $\begin{array}{l}\text { Četnost zařazení počítačových } \\
\text { her učitelkami do 40 let věku }\end{array}$ & \multicolumn{1}{c|}{ Četnost } \\
\hline každý den & 1 \\
\hline několikrát týdně & 6 \\
\hline 1 x týdně & 5 \\
\hline 1 x za 14 dní & 3 \\
\hline méně často & 5 \\
\hline počítač děti nemají k dispozici & 11 \\
\hline
\end{tabular}

Tab. č. 7: Četnost hraní poč. her - do 40 let

\begin{tabular}{|l|r|}
\hline $\begin{array}{l}\text { Četnost zařazení počítačových } \\
\text { her učitelkami nad 41 let věku }\end{array}$ & \multicolumn{1}{c|}{ Četnost } \\
\hline každý den & 6 \\
\hline několikrát týdně & 11 \\
\hline 1x týdně & 7 \\
\hline 1x za 14 dní & 1 \\
\hline méně často & 6 \\
\hline počítač děti nemají k dispozici & 9 \\
\hline
\end{tabular}

Tab. č. 8: Četnost hraní poč. her - nad 41 let

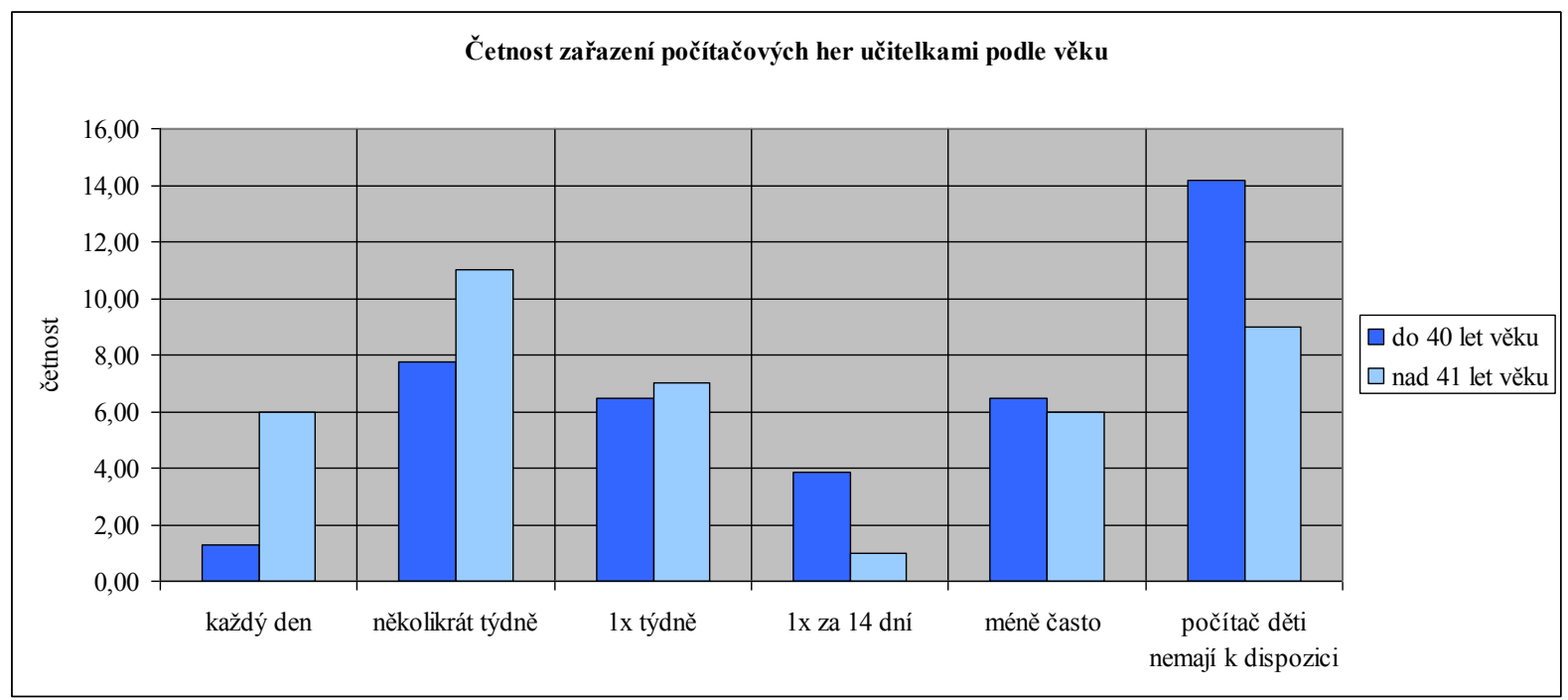

Graf č. 6: Četnost hraní počítačových her-srovnání dle věku pedagogů

Dále jsme provedli třídění podle toho, zda mají pedagogové středoškolské nebo vysokoškolské (příp. vyšší odborné) vzdělání

Bylo předpokládáno, že respondenti s vyšším odborným a vysokoškolským vzděláním budou počítačové hry pro děti v mateřské škole zařazovat častěji, než jejich středoškolsky vzdělané kolegyně, sonda ukázala opak. S menší frekvencí hraní počítačových her se setkávají děti svěřené učitelkám s vy̌šśím odborným nebo vysokoškolským vzděláním. 


\begin{tabular}{|l|r|}
\hline $\begin{array}{l}\text { Četnost zařazení počítačových her } \\
\text { učitelkami s VOŠ a VŠ vzděláním }\end{array}$ & Četnost \\
\hline každý den & 2 \\
\hline několikrát týdně & 6 \\
\hline 1x týdně & 3 \\
\hline 1x za 14 dní & 4 \\
\hline méně často & 9 \\
\hline počítač děti nemají k dispozici & 8 \\
\hline
\end{tabular}

$\Sigma 32$

Tab. č. 9: Četnost hraní poč. her - s VOŠ a V̌̌ vzděláním

\begin{tabular}{|l|r|}
\hline $\begin{array}{l}\text { Četnost zařazení počítačových her } \\
\text { učitelkami se SŠ vzdéláním }\end{array}$ & Četnost \\
\hline každý den & 5 \\
\hline několikrát týdně & 8 \\
\hline 1 x týdně & 9 \\
\hline 1x za 14 dní & 1 \\
\hline méně často & 4 \\
\hline počítač děti nemají k dispozici & 12 \\
\hline
\end{tabular}

Tab. č. 10: Četnost hraní poč. her - se SS̆ vzděláním

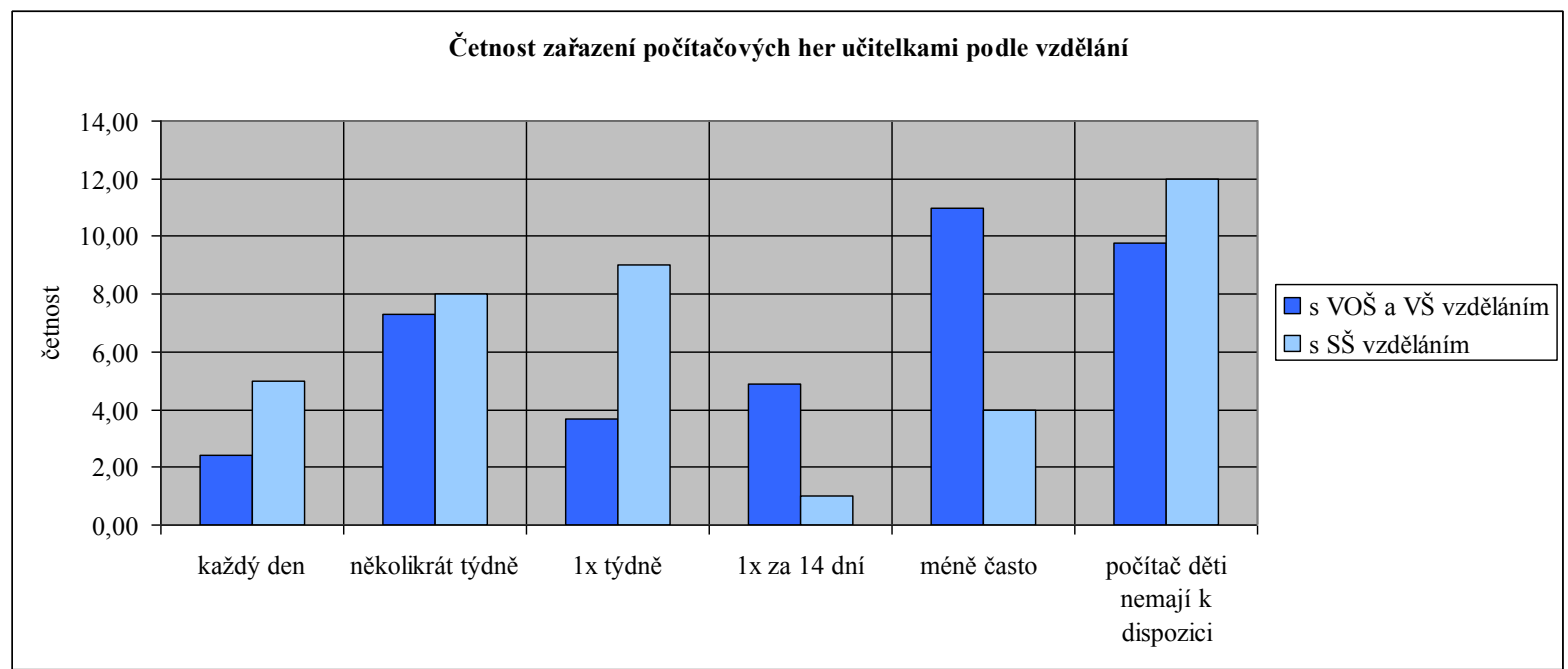

Graf č. 7: Četnost hraní počítačových her - srovnání dle vzdělání pedagogů

Lze oprávněně předpokládat, že se mohou projevit rozdíly $\mathrm{v}$ četnosti zařazování počítačových her do výchovně-vzdělávacího procesu v MŠ mezi školami na vesnici a ve městě. Proto jsme provedli třídění i dle tohoto kritéria.

\begin{tabular}{|l|r|}
\hline $\begin{array}{l}\text { Četnost zařazení počítačových her } \\
\text { učitelkami pracujícími v městských } \\
\text { MŠ }\end{array}$ & Četnost \\
\hline každý den & 2 \\
\hline několikrát týdně & 6 \\
\hline 1x týdně & 4 \\
\hline 1x za 14 dní & 2 \\
\hline méně často & 3 \\
\hline počítač děti nemají k dispozici & 3 \\
\hline
\end{tabular}

Tab. č. 11 Četnost hraní poč. her - pracujicí $v$ městských MS̆

\begin{tabular}{|l|r|}
\hline $\begin{array}{l}\text { Četnost zařazení počítačových her } \\
\text { učitelkami pracujícími ve } \\
\text { vesnických MŠ }\end{array}$ & Četnost \\
\hline každý den & 3 \\
\hline několikrát týdně & 11 \\
\hline $1 x$ týdně & 8 \\
\hline 1 x za 14 dní & 3 \\
\hline méně často & 9 \\
\hline počítač děti nemají k dispozici & 17 \\
\hline
\end{tabular}

Tab. č. 12: Četnost hraní poč. her - pracující ve vesnických Mঙ̆

Komparace výsledků tříděných dle lokality, ve které se mateřská škola nachází, podává následující výsledek: děti v městských mateřských školách mohou hrát počítačové hry častěji než děti na vesnici. Znatelný je zvláště $\mathrm{v}$ této kategorii rozdíl mezi př́stupem $\mathrm{k}$ počítači u mateřských škol na vesnici a ve městě vůbec. 


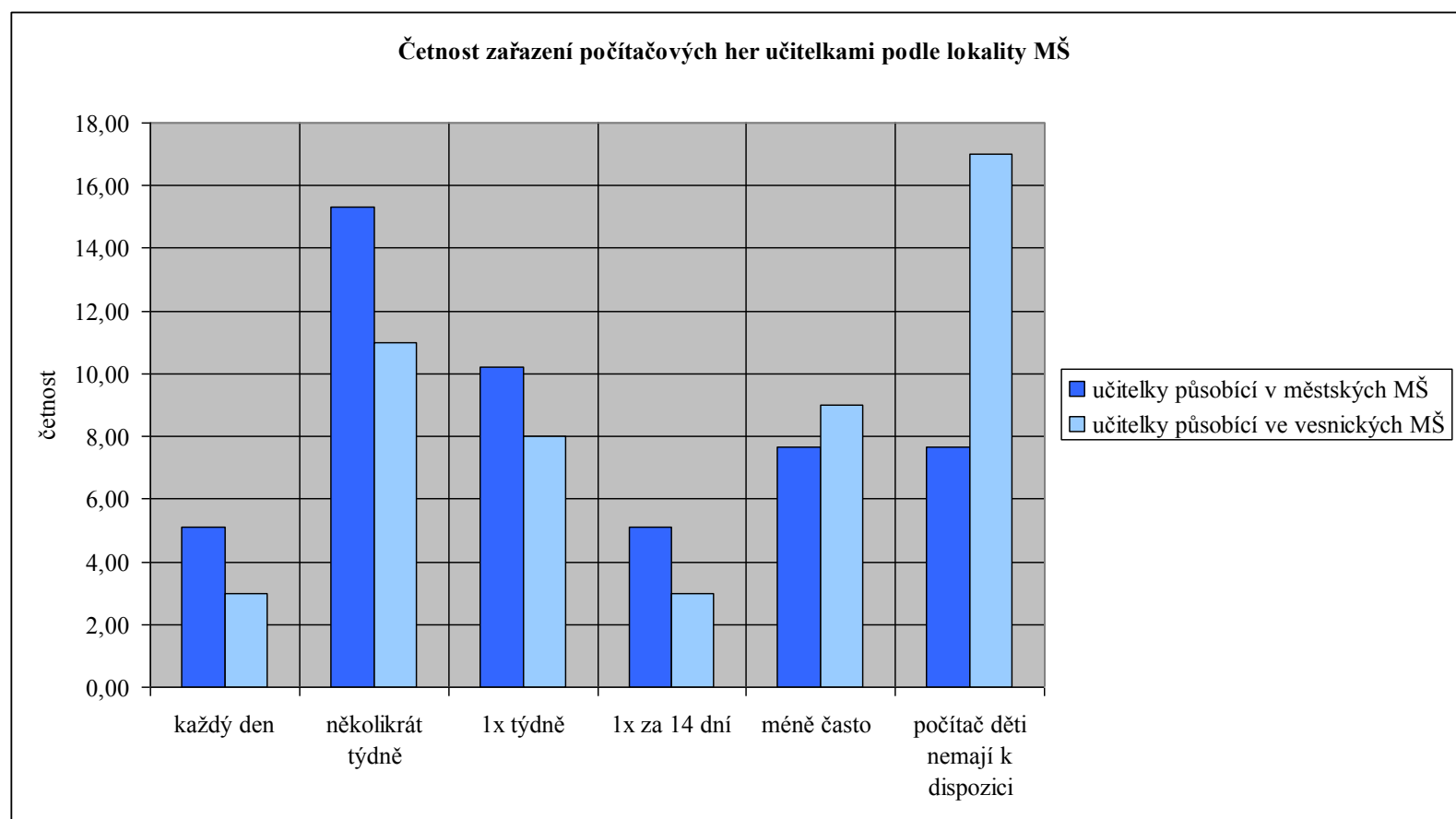

Graf č. 8: Četnost hraní počítačových her - srovnání dle lokality

Během dne děti v MŠ absolvují řadu činností, při kterých mohou být počítače vhodně využity. Bylo žádoucí zjistit, jak je využívání počítače rozloženo mezi jednotlivé činnosti dětí.

Zjistili jsme, že nejčastěji, a to téměř shodně, využívají učitelky mateřských škol počítač jako nabídku činností v ranních hrách a alternativu při náhradních aktivitách (místo odpoledního odpočinku pro nespavé děti, místo pobytu venku při nepř́iznivém počasí, aj.) - celkem $63 \%$ dotazovaných. Ostatních $14 \%$ respondentů pak počítač uplatní $\mathrm{v}$ didakticky zaměřených činnostech. Možnost jiné dotazovaní neupřesnili.

Dotazníková položka: Ve které části dne zařazujete počitač pro děti?

\begin{tabular}{|l|r|}
\hline Zařazení počítače v části dne & Četnost \\
\hline ranní hry & 35 \\
\hline didakticky zacílené činnosti & 16 \\
\hline $\begin{array}{l}\text { náhradní aktivity (místo odpoledního } \\
\text { odpočinku pro nespavé děti, místo } \\
\text { pobytu venku při nepříznivém počasí, } \\
\text { aj.) }\end{array}$ & 36 \\
\hline jiné & 5 \\
\hline počítač děti nemají k dispozici & 20 \\
\hline
\end{tabular}

Tab. č. 13: Zařazení počítače v části dne
Další dotazníková položka se zaměřila na respektování pravidel hygieny při práci dětí na počítači. Bylo zjištěno, že 59 \% respondentů vede děti k uplatňování zásad hygieny. Jen $7 \%$ menšina učitelek odmítá, že by děti při zařazování počítače do výuky vedly k určitým pravidlům hygieny práce na počítači. Ostatní 4 učitelky uvedly, že neví, nebo neznají pravidla, kterými se řídí hygiena práce.

Dotazníková položka: Domniváte se, že vedete dèti ve Vaši MŠ k respektováni pravidel hygieny při práci na počitači?

\begin{tabular}{|l|r|}
\hline Respektování pravidel hygieny & Četnost \\
\hline ano & 35 \\
\hline spíše ano & 7 \\
\hline nevím & 4 \\
\hline spíše ne & 3 \\
\hline ne & 2 \\
\hline počítač děti nemají k dispozici & 20 \\
\hline
\end{tabular}

Tab. č. 14: Respektování pravidel hygieny

Dále jsme se zaměřili za zjištění skutečnosti, jaký význam počítačovým hrám respondenti přikládají v porovnání s ostatními hrami. Nejvíce respondentů $(31 \%)$ chápe počítačové hry v souvislosti s předškolním vzděláváním jako doplňkové. Ostatní učitelky se prakticky 
rovnoměrně zařadily do kategorií, z nichž jedna počítačovým hrám přisuzuje velmi významné, atraktivní až prioritní postavení mezi hrami, druhá skupina je považuje za nevýznamné. Je zřetelné, že názory jsou rozporuplné.

Dotazníková položka: Jaké má počitačová hra postaveni mezi hrami dětí předškolního věku?

\begin{tabular}{|c|c|c|}
\hline & Odpověd' respondentů & Četnost \\
\hline $8 \%$ & $\begin{array}{l}\text { Prioritní, zásadní, silné, je } \\
\text { na prvním místě }\end{array}$ & 6 \\
\hline $7 \%$ & Významné & 5 \\
\hline $18 \%$ & Oblíbené, atraktivní & 13 \\
\hline $31 \%$ & $\begin{array}{l}\text { Doplňkové, zpestření, } \\
\text { orientace v technice }\end{array}$ & 21 \\
\hline $3 \%$ & Specifické, zvláštní & 2 \\
\hline $6 \%$ & $\begin{array}{l}\text { Není hrou v pravém slova } \\
\text { smyslu, ani tak, ani tak, } \\
\text { neví }\end{array}$ & 4 \\
\hline $4 \%$ & Malé & 3 \\
\hline $15 \%$ & $\begin{array}{l}\text { Okrajové, nevýznamné, } \\
\text { nedominantní, nezásadní }\end{array}$ & 11 \\
\hline $8 \%$ & Žádné & 6 \\
\hline
\end{tabular}

$\Sigma 71$

Následovalo zjištění postojů k zařazování počítačových her $\mathrm{v}$ prostř̌edí mateřských škol a zavádění počítačů do předškolního vzdělávání.

Dohromady $46 \%$ respondentů uvádí kladný postoj k zavádění počítačů do vzdělávacího procesu předškolního vzdělávání. Dalších $23 \%$ je v tomto ohledu rezervovanějších, mají k implementaci výhrady. Poslední větší skupinu, tj. celkem $24 \%$ dotázaných tvoří ty učitelky, které na tuto problematiku pohlíží negativně a bez počítače pro děti by se ve své mateřské škole obešly.

Dotazníková položka: Jak pohližite na využiváni počitačových her v prostředi mateřských škol a zaváděni počitače do predškolního vzděláváni?

\begin{tabular}{|c|l|c|}
\hline & Odpověd' respondentů & Četnost \\
\hline $6 \%$ & $\begin{array}{l}\text { Velmi pozitivně, patř́ do } \\
\text { vzdělávání již od mateřské } \\
\text { školy }\end{array}$ & 4 \\
\hline $40 \%$ & Kladně & 29 \\
\hline $23 \%$ & $\begin{array}{l}\text { Jen okrajově, jako doplněk } \\
\text { činností, v omezené míře }\end{array}$ & 16 \\
\hline $7 \%$ & Ani tak, ani tak, neví & 5 \\
\hline $13 \%$ & $\begin{array}{l}\text { Spíše nesouhlasí, je to } \\
\text { zbytečné, není to nutné }\end{array}$ & 9 \\
\hline
\end{tabular}

\begin{tabular}{|l|lr|c|}
\hline $11 \%$ & $\begin{array}{l}\text { Negativně, nepatří do } \\
\text { mateřské } \\
\text { zavádění }\end{array}$ & 8 \\
\hline
\end{tabular}

Pozoruhodné bylo rozklíčování atraktivnosti počítačových her pro děti předškolního věku. Atraktivitu počítačových her pro děti přisuzuje $33 \%$ dotázaných učitelek líbivému grafickému zpracování, množství audiovizuálních efektů a jejich rychlé proměnlivosti. Další početná skupina 15 učitelek se domnívá, že jsou zajímavé pro svou jednoduchost a malé nároky na přemýšlení. $\quad 20 \quad \%$ respondentů $\mathrm{v}$ nich vidí činnost, kterou se snaží děti napodobovat. Zbylé odpovědi udávají ztotožnění s hrdinou, prožití nemožného, možnost opakování, aj.

Dotazníková položka: Zjakého di̊vodu jsou podle Vás počitačové hry pro předškolni děti tolik atraktivní?

\begin{tabular}{|c|l|c|}
\hline & Odpověd' respondentů & Četnost \\
\hline $33 \%$ & $\begin{array}{l}\text { Grafika, zvukové efekty, } \\
\text { barevnost, obrázky a jejich } \\
\text { proměnlivost }\end{array}$ & 23 \\
\hline $21 \%$ & $\begin{array}{l}\text { Jsou jednodušší oproti } \\
\text { skutečným hrám s herním } \\
\text { partnerem, jsou pohodlné, } \\
\text { kdykoliv dostupné, } \\
\text { neměnné, pasivní zábava }\end{array}$ & 15 \\
\hline $20 \%$ & $\begin{array}{l}\text { Napodobení dospělých, } \\
\text { starších sourozenců }\end{array}$ & 14 \\
\hline $10 \%$ & $\begin{array}{l}\text { Možnost stát se někým } \\
\text { jiným, zažít to, co jindy } \\
\text { nelze }\end{array}$ & 7 \\
\hline $7 \%$ & $\begin{array}{l}\text { Náprava chyby, více řešení, } \\
\text { více postupů, další možnost } \\
\text { opakování, okamžitá zpětná } \\
\text { vazba }\end{array}$ & 5 \\
\hline $4 \%$ & $\begin{array}{l}\text { Suplují jinou aktivitu, př́íp. } \\
\text { hrového partnera, který } \\
\text { není k dispozici }\end{array}$ & 3 \\
\hline $4 \%$ & Nevím & 3 \\
\hline $1 \%$ & Nejsou atraktivní & 1 \\
\hline
\end{tabular}

Hraní počítačových her má své klady i negativa. Bylo zjištěno, že téměř polovina dotázaných (46\%) dělí své odpovědi ohledně prrínosu počítačových her $\mathrm{v}$ předškolním vzdělávání tak, že hry mohou zlepšovat postřeh, pamět', pozornost, myšlení, aj., druhá stejně 
početná skupina $\mathrm{v}$ hraní nenachází žádný přínos. Další mají $\mathrm{k}$ př́nosům počítačových her výhrady a připomínky, ovšem uznávají jejich klady při obsluze počítačové techniky.

Dotazníková položka: Spatrujete vhraní počitačových her dětmi predškolního věku nějaký prínos?

\begin{tabular}{|c|c|c|}
\hline & Odpověd' respondentů & Četnost \\
\hline $23 \%$ & $\begin{array}{l}\text { Zlepšení postřehu, } \\
\text { orientace, logického } \\
\text { uvažování, paměti, jemné } \\
\text { motoriky, pozornosti, } \\
\text { myšlení, volba rozhodování } \\
\text { z více postupů, kombinační } \\
\text { schopnosti, rychlé reakce, } \\
\text { soustředění }\end{array}$ & 16 \\
\hline $23 \%$ & Ne, žádný př́ínos & 16 \\
\hline $17 \%$ & $\begin{array}{l}\text { Spíše ano, záleží na druhu } \\
\text { hry, výběr her, specifické } \\
\text { pro danou věkovou } \\
\text { kategorii, přiměřeně }\end{array}$ & 12 \\
\hline $13 \%$ & $\begin{array}{l}\text { Seznámení } \text { s technikou } \\
\text { ještě před vstupem do } Z \text { Š, } \\
\text { čím dř́ive, tím lépe pro } \\
\text { budoucí život }\end{array}$ & 9 \\
\hline $10 \%$ & Ano & 7 \\
\hline $4 \%$ & $\begin{array}{l}\text { Ne př́lišs, uznává spíše } \\
\text { didaktické } \\
\text { programy }\end{array}$ & 3 \\
\hline $4 \%$ & $\begin{array}{l}\text { Minimální př́nos, jen do } \\
\text { jisté míry }\end{array}$ & 3 \\
\hline $4 \%$ & $\begin{array}{l}\text { Rozšiření vzdělávací } \\
\text { nabídky, atraktivní způsob } \\
\text { vyhledávání informací }\end{array}$ & 3 \\
\hline $1 \%$ & Relaxační př́nos & 1 \\
\hline $1 \%$ & Nevím & 1 \\
\hline
\end{tabular}

$38 \%$ respondentů spatřuje rizikovost hraní počítačových her ve vzniku možné závislosti na tomto a varují před množstvím času, které děti u počítače stráví. Další se obávají o sociální aktivity dětských hráčů a jejich možné problémy v komunikaci s vrstevníky. $10 \%$ učitelek vidí v počítačových hrách nebezpečí ztráty fantazie a tvořivosti dětí. Ostatní akcentují nezdravý životní styl, agresivitu a problémy s nerozlišením hry a skutečnosti.
Dotazniková položka: Spatřujete vhraní počitačových her dětmi predškolního věku nějaká úskalí?

\begin{tabular}{|c|c|c|}
\hline & Odpověd' respondentů & Četnost \\
\hline $38 \%$ & $\begin{array}{l}\text { Návykovost, rozvoj možných } \\
\text { závislostí, trávení hodně času }\end{array}$ & 28 \\
\hline $13 \%$ & $\begin{array}{lr}\text { Omezení } & \text { kontaktu } \\
\text { s vrstevníky, } & \text { problémy } \\
\text { v sociální } & \text { oblasti, } \\
\text { komunikace } & \end{array}$ & 9 \\
\hline $10 \%$ & $\begin{array}{l}\text { Ztráta fantazie, tvořivosti, } \\
\text { omezení dalších aktivit }\end{array}$ & 7 \\
\hline $10 \%$ & $\begin{array}{l}\text { Nebezpečné } \text { z hlediska } \\
\text { zdravého životního stylu, } \\
\text { problematické } \\
\text { nedodržování hygieny práce } \\
\text { na počítači }\end{array}$ & 7 \\
\hline $10 \%$ & Ano & 7 \\
\hline $7 \%$ & Zvyšují agresivitu & 5 \\
\hline $6 \%$ & $\begin{array}{l}\text { Riziko v podobě nerozlišení } \\
\text { reality a fikce ve hře }\end{array}$ & 4 \\
\hline $6 \%$ & $\begin{array}{l}\text { Ne; ne, pokud jsou rrízeny } \\
\text { učitelkou }\end{array}$ & 4 \\
\hline
\end{tabular}

$\Sigma 71$

Šetřením jsme dále zjistili, že učitelky nejčastěji organizují aktivitu dětí u počítače tak, aby se vystř́idaly ty děti, které o toto mají zájem. Počítačové hraní probíhá většinou ve 2-3 hráčích $\mathrm{u}$ počítače zároveň. $17 \%$ respondentů se domnívá, že by měl počítač sloužit k podpoře týdenních témat. Další navrhují ohlídat čas, po který dítě hraje a dbát na dodržování pravidel.

Dotazniková položka: Jak by podle Vás měla učitelka v mateřské škole, která využivá počitačové hry organizovat tyto aktivity děti?

\begin{tabular}{|l|l|c|}
\hline & Odpověd' respondentı̊ & Četnost \\
\hline $20 \%$ & $\begin{array}{l}\text { Mít u počítače 2-3 děti, } \\
\text { prostř́dat }\end{array}$ & 14 \\
\hline $17 \%$ & $\begin{array}{l}\text { Propojovat s týdenními } \\
\text { tématy, motivovat, } \\
\text { komentovat hraní }\end{array}$ & 12 \\
\hline $15 \%$ & $\begin{array}{l}\text { Zařadit do ranních her při } \\
\text { scházení, při rozcházení, } \\
\text { jako náhradní aktivity }\end{array}$ & 11 \\
\hline $14 \%$ & $\begin{array}{l}\text { Zařazovat stř́dmě, za } \\
\text { odměnu }\end{array}$ & 10 \\
\hline $11 \%$ & $\begin{array}{l}\text { Hlídat čas, po který dítě } \\
\text { hraje }\end{array}$ & 8 \\
\hline
\end{tabular}




\begin{tabular}{|c|c|c|}
\hline $7 \%$ & $\begin{array}{l}\text { U počítače jen jedno dítě, } \\
\text { individuální práce - dítě } \\
\text { s odkladem } \\
\text { docházky, integrované dítě }\end{array}$ & 5 \\
\hline $6 \%$ & $\begin{array}{l}\text { Stanovit pravidla, dbát na } \\
\text { jejich dodržování }\end{array}$ & 4 \\
\hline $4 \%$ & Nevím, nemám zkušenosti & 3 \\
\hline $3 \%$ & 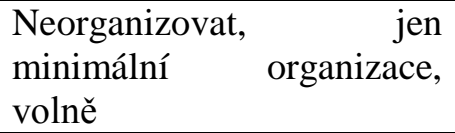 & 2 \\
\hline $3 \%$ & $\begin{array}{l}\text { Nezařazovat vůbec } \\
\text { počítačové hry do mateřské } \\
\text { školy }\end{array}$ & 2 \\
\hline
\end{tabular}

$\Sigma 71$

Zjistili jsme taktéž, že $41 \%$ učitelek se shoduje $\mathrm{v}$ tom, že je třeba dát dětem časový limit pro hraní na počítači, aby nedocházelo k jednostrannému zatížení. 10 \% doporučuje, aby hry, které budou děti hrát, pečlivě vybírala učitelka. Dalších $10 \%$ nemá nastavená pravidla pro hraní. 6 učitelek upozorňuje na stř́idání dětí u počítače a 4 akcentují hygienu práce. Lze říci, že při zavedení počítače do mateřské školy se bez určitých nastavených pravidel neobejdeme.

Dotazníková položka: Doporučujete nějaká pravidla pro děti prí hrani počitačových her $v$ mateřské škole?

\begin{tabular}{|c|c|c|}
\hline & Odpověd' respondentů & Četnost \\
\hline $41 \%$ & Časové omezení & 29 \\
\hline $10 \%$ & Hry vybrané učitelkou & 7 \\
\hline $10 \%$ & $\mathrm{Ne}$ & 7 \\
\hline $8 \%$ & $\begin{array}{l}\text { Prostř́dat všechny děti, } \\
\text { které mají zájem }\end{array}$ & 6 \\
\hline $8 \%$ & Ano & 6 \\
\hline $6 \%$ & $\begin{array}{l}\text { Hygiena práce }- \text { sezení, } \\
\text { vzdálenost oči } \quad \text { od } \\
\text { monitoru }\end{array}$ & 4 \\
\hline $6 \%$ & $\begin{array}{l}\text { Spolupráce dětí mezi } \\
\text { sebou }\end{array}$ & 4 \\
\hline $4 \%$ & $\begin{array}{l}\text { Pravidla vytvořená spolu } \\
\text { s dětmi, domluvit se na } \\
\text { nich }\end{array}$ & 3 \\
\hline $3 \%$ & Nevím & 2 \\
\hline $3 \%$ & $\begin{array}{l}\text { Nepodporuji počítačové } \\
\text { hry v mateřské škole }\end{array}$ & 2 \\
\hline $1 \%$ & $\begin{array}{l}\text { Práce jednotlivců, v klidu, } \\
\text { bez rušení ostatních }\end{array}$ & 1 \\
\hline
\end{tabular}


radosti - a vztah $\mathrm{k}$ těmto nádherným hodnotám při hrách na PC nezískají (pedagožka do 40 let, VŠ, na vesnici).

V dnešní době je znalost práce na počítači nutností, jeho obsluha by tedy měla být jedním z cílů vzdělávání. Je na zvážení pedagoga, jak tento úkol uchopí, aby nedocházelo ke zneužívání (odkládání dětí k počítači) (pedagožka nad 41 let, VŠ, ve městě).

$\mathrm{V}$ žádném případě by neměly $\mathrm{v} M S \breve{S}$ mít děti k dispozici hry s prvky agrese (pedagožka nad 41 let, VŠ, na vesnici).

Časté hraní počítačových her by nemělo nahrazovat kolektivní činnosti a spontánní hry dětí (pedagožka nad 41 let, SŠ, na vesnici).

Ideální by byl koutek pro děti ve třídě (pedagožka nad 41 let, SŠ, na vesnici).

Počítače by neměly nahradit vlastní hry dětí s hračkami, s ostatními dětmi. Měly by se využívat uváženě a promyšleně - spíš méně než více. Vždyt' počítače budou děti provázet po celý život, tak proč se na něj upínat už $\mathrm{v}$ MŠ (pedagožka nad 41 let, VŠ, ve městě).

Inspekce sleduje rozvoj informační gramotnosti i na MŠ, děti se mají seznamovat $\mathrm{s}$ moderní technikou, také s interaktivní tabulí, ale vždy v rámci dohodnutých pravidel (pedagožka nad 41 let, SŠ, na vesnici).

Počítače $v$ MŠ jsou dle mého názoru zbytečný a nezdravý luxus. Děti v tomto věku potřebují rozvíjet své psychické předpoklady a ne sedět u PC (pedagožka nad 41 let, VŠ, na vesnici).

\section{Závěr}

V tomto článku se podařilo úspěšně navázat na dříve publikované domácí i zahraniční práce (1), (2), (3), (4), 5, (6), (7), a (8). Cílem realizované výzkumné sondy nebylo podat zobecnitelné závěry a zjištění, avšak poukázat na stav a možné problémy, které by měly být dále reliabilně zkoumány. $\mathrm{Mj}$. se podařilo prokázat, že využití počítače a počítačových her má rozporuplný charakter. Na jedné straně existuje skupina př́znivců, kteří počítače každodenně využívají, na druhé straně jsou pedagogové, kteří využívání počítačů zavrhují.

\section{Literatura}

(1) Speciálni dètské počitače IBM zamírily do školek v Ostravě. Citováno dne 5. 9. 2012. Dostupné na: http://www.ibm.com/news/cz/cs/ 2011/02/15/b002717u77890y78.html.
(2) SERPE, A. KidSmart: an essential tool for mathematical education in nursery schools. In Learning to Live in the Knowledge Society IFIP 20th World Computer Congress. Milano: IFIP, 2008. p. 313 - 320. ISBN978-0-387-09728-2.

(3) DOSTÁL, J. Výukový software a počítačové hry - nástroje moderního vzdělávání. Journal of Technology and Information Education. 2009, Olomouc - EU, Univerzita Palackého, Ročník 1, Číslo 1, s. 24 - 28. ISSN 1803-537X (print). ISSN 1803-6805 (on-line).

(4) HOTTA, H. - FUJII, K. The Current Status for Children Playing with Multimedia in ChildCare:Deployment of the "KidSmart Early Learning Program" in Japan. In G. Siemens \& C. Fulford (Eds.), Proceedings of World Conference on Educational Multimedia, Hypermedia and Telecommunications 2009. pp. 2396 - 2408. Chesapeake, VA: AACE. Honolulu, HI, USA June 22, 2009. ISBN 1-880094-73-8

(5) MCKENNEY, S. - VOOGT, J. Technology and young children: How 4-7 year olds perceive their own use of computers. Computers in Human Behavior, Volume 26, Issue 4, July 2010, Pages 656-664, ISSN 0747-5632.

(6) KOŽUCHOVÁ, M. 2007. Diet'a predškolského veku a počítač. In : Infotech 2007. Olomouc: Votobia, 2007. ISBN 978-80-7220301-7.

(7) KOCHOVÁ, H. Počítač a diet'a predškolského veku In Súčasnost' a budúcnost' predprimárnej edukácie. Prešov: PU, 2009. s. 141 - 145. ISBN 978-80-555-0006-5.

(8) ŠMELOVÁ, E. Mateřská škola: teorie a praxe I. Olomouc: Univerzita Palackého, 2004. 168 s. ISBN 80-244-0945-3.

Mgr. Michaela Hamplová

Mateřská škola Bělkovice-Lašt’any, Bělkovice-Lašt'any 194, 78316 Dolany, ČR

E-mail: michaela.hamplova@seznam.cz

Www pracovišstě: www.skolabelkovice.cz

PaedDr. PhDr. Jiř́i Dostál, Ph.D.

Katedra technické a informační výchovy

Pedagogická fakulta UP

Žižkovo nám. č. 5

771 40, Olomouc, ČR

Tel: +420 585635813

E-mail: j.dostal@upol.cz

Www pracoviště: www.kteiv.upol.cz 